DOI: $10.19195 / 0137-1134.117 .5$

\author{
ELIZA MAZURCZAK-JASIŃSKA \\ ORCID: 0000-0003-2412-2427 \\ Uniwersytet Wrocławski
}

\title{
KODEKSOWA OCHRONA SZCZEGÓLNA STOSUNKU PRACY POWSTAŁEGO NA PODSTAWIE POWOŁANIA
}

\begin{abstract}
Abstrakt: Przedmiotem opracowania jest analiza mechanizmów prawnych przewidzianych w Kodeksie pracy mających na celu ochronę stosunku pracy pracowników powołanych, zarówno pod kątem zakresu podmiotowego, jak i warunków prawidłowości zastosowania tych środków ochronnych przez organ odwołujący (pracodawcę). Wśród podstaw nawiązania stosunku pracy powołanie wyróżnia się najmniejszym zakresem stabilizacji nie tylko ze względu na zakres roszczeń przysługujących pracownikom w razie odwołania oraz wyłączenie możliwości zastosowania trybów postępowania przy rozwiązywaniu umów o pracę, lecz także ze względu na fragmentaryczny charakter ochrony szczególnej, która nie dość, że uniemożliwia odwołanie pracownika z zajmowanego stanowiska, to dodatkowo w niewielkim stopniu utrudnia rozwiązanie stosunku pracy. Sytuacja pracowników powołanych w zakresie stabilizacji zatrudnienia może przedstawiać się korzystniej jedynie wtedy, gdy będą tak stanowić pozakodeksowe przepisy szczególne. W porównaniu do ochrony szczególnej przysługującej pracownikom umownym środki ochrony zatrudnienia z powołania przewidziane w Kodeksie pracy mają ograniczony zakres podmiotowy. Ustawodawca zrezygnował również z bezwzględnego zakazu rozwiązywania stosunku pracy na rzecz przedłużenia trwania dotychczasowego stosunku pracy lub kontynuacji zatrudnienia u dotychczasowego pracodawcy, lecz na innej podstawie prawnej.
\end{abstract}

Słowa kluczowe: powołanie, ciąża, ochrona w wieku przedemerytalnym, ochrona szczególna

\section{UWAGI WSTĘPNE}

Powołanie stanowi jedną z pozaumownych podstaw nawiązania stosunku pracy. Zgodnie z przepisem art. $68 \S 1$ ustawy z dnia 26 czerwca 1974 roku — Kodeks $\operatorname{pracy}^{1}$ (dalej: k.p.) stosunek pracy nawiązuje się na podstawie powołania w przypadkach określonych w odrębnych przepisach ${ }^{2}$. Oznacza to, że w razie braku regulacji prawnej wskazującej wyraźnie na tę podstawę zatrudnienia na danym stanowisku powołania nie można domniemywać. Wśród aktów prawnych zawierających posta-

1 Tekst jedn. Dz.U. z 2018 r. poz. 917 z późn. zm.

2 Szerzej na temat użytego przez ustawodawcę zakresu pojęcia „odrębne przepisy” zob. B.M. Ćwiertniak, [w:] Kodeks pracy. Komentarz, red. K.W. Baran, Warszawa 2014, s. 511. 
nowienia umożliwiające obsadzenie stanowisk na podstawie aktu powołania można między innymi wymienić: ustawę z dnia 21 listopada 2008 roku o pracownikach samorządowych $^{3}$ (zastępca wójta (burmistrza, prezydenta miasta), skarbnik gminy, skarbnik powiatu, skarbnik województwa); ustawę z dnia 25 września 1981 roku o przedsiębiorstwach państwowych ${ }^{4}$ (dyrektor przedsiębiorstwa państwowego); ustawę z dnia 13 kwietnia 2007 roku o Państwowej Inspekcji Pracy 5 (między innymi okręgowy inspektor pracy i jego zastępca, dyrektor i wicedyrektor Gabinetu Głównego Inspektora Pracy) czy też ustawę z dnia 25 października 1991 roku o organizowaniu i prowadzeniu działalności kulturalnej ${ }^{6}$ (dyrektor instytucji kultury). Akt powołania stanowi również podstawę nawiązania stosunku pracy z nielegitymującymi się statusem funkcjonariusza szefami (kierownikami) służb mundurowych ${ }^{7}$.

Powołanie w większości przypadków jest aktem organizacyjnym o podwójnym charakterze - powierzającym danej osobie określone funkcje (stanowisko), prowadzącym do nawiązania między tą osobą a organem powołującym stosunku podporządkowania (zależności służbowej) o charakterze organizacyjnym (publicznoprawnym) i jednocześnie nawiązującym stosunek pracy między osobą powołaną a jednostką organizacyjną, w której ma ona objąć powierzone stanowisko ${ }^{8}$. Biorąc pod uwagę treść regulacji ustawowych, kompetencja do dokonania aktu powołania przysługuje najczęściej: podmiotowi uprawnionemu do wykonywania czynności w sprawach z zakresu prawa pracy u danego pracodawcy (na przykład wójtowi wobec zastępcy wójta), organowi leżącemu poza strukturą pracodawcy mającego zatrudnić powołanego pracownika (na przykład organizator wobec dyrektora instytucji kultury) czy też organowi kolegialnemu pozostającemu w strukturze jednostki mającej zatrudnić pracownika (na przykład rada gminy wobec skarbnika gminy). Zasadniczo stosunek pracy z powołania nawiązuje się na czas nieokreślony, a jeżeli na podstawie przepisów szczególnych pracownik został powołany na czas określony, zatrudnienie obejmuje okres objęty powołaniem (por. art. $68 \S 1^{1}$ k.p.). Jeżeli przepisy Kodeksu pracy regulujące stosunek pracy na podstawie powołania nie stanowią inaczej, do analizowanego pozaumownego stosunku pracy stosuje się przepisy dotyczące umowy o pracę na czas nieokreślony (por. art. 69 zd. 1 k.p.).

3 Tekst jedn. Dz.U. z 2018 r. poz.1260 z późn. zm.

4 Tekst jedn. Dz.U. z 2017 r. poz. 2152.

5 Tekst jedn. Dz.U. z 2018 r. poz. 623 z późn. zm.

6 Tekst jedn. Dz.U. z 2018 r. poz. 1983 z późn. zm.

7 Por. postanowienie WSA w Warszawie z dnia 21 kwietnia 2010 roku, sygn. II SA/Wa 22/10, www.nsa.gov.pl; wyrok WSA w Warszawie z dnia 21 kwietnia 2010 roku, sygn. II SAB/Wa 215/09, www.nsa.gov.pl; M. Czechowski, Status prawny szefa stużby specjalnej oraz komendanta, szefa i dyrektora generalnego stużby umundurowanej, [w:] Księga pamiątkowa w piata rocznice śmierci profesora Andrzeja Kijowskiego, red. Z. Niedbała, Warszawa 2010, s. 39.

8 Por. T. Kuczyński, [w:] H. Szurgacz et al., Prawo pracy. Zarys wykładu, Warszawa 2016, s. 347. 


\section{ODWOŁANIE ZE STANOWISKA}

Rozwiązanie stosunku pracy z powołania następuje w wyniku odwołania ze stanowiska (funkcji). Co do zasady odwołanie jest odwrotnością czynności powołania do pełnienia określonej funkcji. W konsekwencji zatem stanowi również akt wywołujący podwójny skutek prawny — w sferze publicznoprawnej pozbawia uprawnień do wykonywania funkcji publicznej, a w sferze zobowiązaniowej rozwiązuje stosunek pracy łączący pracownika z podmiotem, w którym zajmował on swoje stanowisko (pełnił funkcję). Stosunek pracy z pracownikiem odwołanym ze stanowiska rozwiązuje się na zasadach określonych w Kodeksie pracy, chyba że przepisy szczególne stanowią inaczej (por. art. $70 \S 1^{2}$ k.p.). Odwołanie powinno być dokonane na piśmie. Czynność ta może zostać dokonana przez organ, który powołał zatrudnionego na stanowisko w każdym czasie — niezwłocznie lub w określonym terminie. W tym wypadku nie znajdą zastosowania, na mocy wyraźnego wyłączenia zawartego w Kodeksie pracy, przepisy regulujące: tryb postępowania przy rozwiązywaniu umów o pracę, rozpatrywanie sporów ze stosunku pracy w części dotyczącej orzekania o bezskuteczności wypowiedzenia (przywracaniu do pracy). Podkreśla się, że celem, do jakiego dążył ustawodawca, regulując instytucję ustania analizowanego pozaumownego stosunku zatrudnienia, było znaczne ułatwienie jego rozwiązania przez pracodawcę oraz pozbawienie pracownika roszczeń mających na celu kontynuację zatrudnienia lub reaktywowanie stosunku pracy ${ }^{9}$. Niewątpliwy wpływ na znaczne osłabienie trwałości zatrudnienia ma w tym przypadku wyłączenie opiniodawczych oraz interwencyjnych form oddziaływania struktur związkowych w sferze ustania zatrudnienia, w szczególności przy powołaniu bezterminowym ${ }^{10} . Z$ tych też względów w judykaturze i doktrynie powołanie określane jest jako najbardziej labilna więź prawna łącząca pracownika z pracodawcą, charakteryzująca się znacznym osłabieniem stabilizacji zatrudnienia ${ }^{11}$.

Stosunek pracy z pracownikiem odwołanym ze stanowiska rozwiązuje się na zasadach określonych w Kodeksie pracy, chyba że przepisy szczególne stanowią inaczej. Na wniosek lub za zgodą pracownika pracodawca może zatrudnić go w okresie wypowiedzenia do innej pracy, odpowiedniej ze względu na jego kwalifikacje zawodowe, a po upływie okresu wypowiedzenia zatrudnić na uzgodnionych przez strony warunkach pracy i płacy (art. 71 k.p.).

${ }^{9}$ K. Jaśkowski, [w:] K. Jaśkowski, E. Maniewska, Kodeks pracy. Komentarz, red. K. Jaśkowski, t. 1, Warszawa 2014, s. 333.

${ }^{10} \mathrm{H}$. Szewczyk, Stabilizacja zatrudnienia pracowników samorzadowych petniacych funkcje $z$ wyboru oraz powolania, [w:] Z problematyki prawa pracy i polityki socjalnej, t. 12, red. A. Nowak, Katowice 1997, s. 74.

11 Zob. wyrok SN z dnia 11 lipca 2017 roku, sygn. I PK 201/16, LEX nr 2397620; oraz wyrok SN z dnia 12 listopada 2014 roku, sygn. II PK 24/14, OSNP 2016, nr 5, poz. 57; por. także B.M. Ćwiertniak, op. cit., s. 528. 


\section{MECHANIZMY OCHRONNE I ZAKRES PODMIOTOWY OCHRONY SZCZEGÓLNEJ}

Co do zasady odwołanie jest zdarzeniem powodującym ustanie zatrudnienia, które może być równoznaczne $\mathrm{z}$ wypowiedzeniem umowy o pracę lub rozwiązaniem umowy o pracę bez wypowiedzenia, jeżeli nastąpiło z przyczyn, o których mowa w art. 52 lub 53 k.p. Oznacza to, że stosunek pracy ustaje odpowiednio w zależności od podstaw, które zadecydowały o odwołaniu - wraz z upływem uwarunkowanego długością stażu pracy okresu wypowiedzenia albo niezwłocznie ${ }^{12}$.

Choć odwołanie ze stanowiska może nastąpić w każdym czasie, a dopuszczalność dokonania tej czynności w każdym momencie na gruncie regulacji kodeksowych nie została prawnie ograniczona ${ }^{13}$, istnieją określone przypadki, w których akt ten powoduje jedynie (przejściowo lub trwale) ustanie więzi o charakterze publicznoprawnym. Przyjmują one postać zmodyfikowanej instytucji bezwzględnej ochrony szczególnej stosunku pracy, uregulowanej w przepisach art. 41, art. 177 i art. 39 Kodeksu pracy, zarówno w aspekcie podmiotowym, jak i pod względem przyjętych przez ustawodawcę konstrukcji środków ochrony. W konsekwencji przyjętych przez ustawodawcę rozwiązań choć odwołany pracownik zostaje pozbawiony stanowiska (funkcji), niezwłocznie (lub w określonym przez organ odwołujący terminie), byt stosunku pracy łączącego go dotychczas z pracodawcą zostaje wydłużony lub zatrudnienie trwa nadal, aczkolwiek na zmienionych przez uprawniony podmiot warunkach.

\subsection{ODWOŁANIE W CZASIE USPRAWIEDLIWIONEJ NIEOBECNOŚCI W PRACY}

Przykładem posłużenia się przez ustawodawcę pierwszą z wymienionych konstrukcji ochronnych są postanowienia przepisu art. $72 \S 1$ zd. 1 k.p., zgodnie z którym jeżeli odwołanie następuje w okresie usprawiedliwionej nieobecności w pracy, bieg wypowiedzenia rozpoczyna się po upływie tego okresu. Zakresem podmiotowym wskazanej regulacji, podobnie jak na gruncie przepisu art. 41 k.p., objęci są pracownicy, których absencja spowodowana jest chorobą, a także tacy, w których przypadku przyczynę usprawiedliwionej nieobecności w pracy stanowi

12 Por. Z. Góral, Prawo pracy w samorządzie terytorialnym, Warszawa 1999, s. 121.

13 Ograniczenia w zakresie dopuszczalności odwołania mogą jednak wynikać z unormowań pozakodeksowych. Niektóre pragmatyki pracownicze zawierają regulacje ochronne zwiększające stabilizację zatrudnienia powołanych pracowników poprzez wprowadzenie katalogu przesłanek mogących stanowić podstawę odwołania ze stanowiska; zob. np. art. 16 ustawy z dnia 24 maja 2002 roku o Agencji Bezpieczeństwa Wewnętrznego oraz Agencji Wywiadu (tekst jedn. Dz.U. z 2018 r. poz. 2387 z późn. zm.) czy też art. 17 ustawy z dnia 9 czerwca 2006 roku o Służbie Kontrwywiadu Wojskowego oraz Służbie Wywiadu Wojskowego (tekst jedn. Dz.U. z 2017 r. poz. 1978 z późn. zm.). Powołani pracownicy są również objęci ochroną szczególną wynikającą z przepisów pozakodeksowych, jeżeli przepisy te jednoznacznie o tym stanowią — tak: A. Dubowik, Powołanie jako podstawa nawiazania stosunku pracy a reforma prawa pracy, „Praca i Zabezpieczenie Społeczne" 2004, nr 6, s. 7 i cytowane tam orzecznictwo. 
przebywanie w tymczasowym areszcie, odbywanie kary pozbawienia wolności czy też sprawowanie opieki nad chorym członkiem rodziny. Obejmuje on również pracowników nieobecnych w pracy z powodu korzystania z przysługujących im uprawnień urlopowych ${ }^{14}$, w tym z urlopu macierzyńskiego ${ }^{15}$ i wychowawczego ${ }^{16}$.

Zastosowany $\mathrm{w}$ tym wypadku mechanizm ochronny polega na wydłużeniu łączącego zatrudnionego z pracodawcą stosunku pracy ponad przysługujący zatrudnionemu okres wypowiedzenia. Choć stanowiska literatury i orzecznictwa odnośnie do wpływu zdarzenia określonego we wskazanej regulacji na bieg okresu wypowiedzenia są podzielone i posługują się między innymi instytucjami: zawieszenia $^{17}$, wstrzymania biegu ${ }^{18}$ czy też przerwania tego okresu, to dominują te opinie zgodne z literalnym brzmieniem wskazanego unormowania, że w tym przypadku dochodzi do wstrzymania jego początku ${ }^{19}$. Bieg uzależnionego od stażu pracy pracownika okresu wypowiedzenia rozpoczyna się zatem dopiero po upływie tego okresu, później niż w chwili skutecznego odwołania pracownika. Nie można zawiesić lub przerwać biegu czegoś, co z powodu przeszkód prawnych nie mogło zostać rozpoczęte. Należy jednak podkreślić, że przyjęcie konkretnej konstrukcji nie jest relewantne prawnie. Celem środka ochrony, którym posłużył się ustawodawca w omawianym przepisie, jest zagwarantowanie pracownikowi, że rozwiązanie stosunku pracy w trybie art. $70 \S 2$ k.p. w okresie jego usprawiedliwionej nieobecności w pracy nie nastąpi wcześniej niż w dniu, w którym nastąpiłoby rozwiązanie z nim stosunku pracy, gdyby w dacie odwołania nie korzystał z ochrony przewidzianej w art. $72 \S 1$ k.p. ${ }^{20}$

14 Przepis art. 41 w sposób wyraźny odwołuje się do urlopu oraz innej usprawiedliwionej nieobecności w pracy. Przyjmuje się, że obejmuje swoim zakresem urlop wypoczynkowy, bezpłatny, szkoleniowy czy dla poratowania zdrowia. Nie dotyczy natomiast tych przerw w wykonywaniu pracy, w których wypadku ustawodawca przewidział korzystniejsze regulacje ochronne. Dalej idąca ochrona niż ta z art. 41 k.p. została przewidziana w odniesieniu do urlopów macierzyńskich, rodzicielskich i ojcowskich, a także wychowawczych. Jest to ochrona bezwzględna wzmożona, polegająca nie tylko na zakazie wypowiedzenia umowy o pracę w okresie ochronnym, lecz także jej rozwiąania.

15 Tak m.in.: M.T. Romer, Kodeks pracy. Komentarz, Warszawa 2012, s. 536; T. Liszcz, Pozaumowne stosunki pracy, [w:] Prawo pracy RP w obliczu przemian, red. M. Matey-Tyrowicz, T. Zieliński, Warszawa 2006, s. 232.

16 Tak: A. Giedrewicz-Niewińska, [w:] Kodeks pracy. Komentarz, red. K. Walczak, wyd. 27, Legalis 2018, komentarz do art. 72.

17 Zob. P. Korus, [w:] Kodeks pracy. Komentarz, red. A. Sobczyk, Warszawa 2015, s. 406; zob. też wyrok Sądu Apelacyjnego w Lublinie z dnia 27 listopada 1996 roku, sygn. III AUa 27/96, LEX nr 28826.

18 Tak: J. Skoczyński, [w:] Kodeks pracy. Komentarz, red. Z. Salwa, Warszawa 1999, s. 231.

19 Tak: B.M. Ćwiertniak, op. cit., s. 552; J. Wratny, Kodeks pracy. Komentarz, Legalis 2016, komentarz do art. 72; J. Stelina, [w:] Kodeks pracy z komentarzem, red. U. Jackowiak, Gdynia 2004, s. 345; zob. też wyrok Sądu Apelacyjnego w Katowicach z dnia 7 października 1992 roku, sygn. III APr 54/92.

20 Uchwała SN z dnia 17 lipca 1981 roku, sygn. I PZP 18/81, OSNC 1982, nr 1, poz. 4. 
Na wzór konstrukcji ochrony szczególnej umownego stosunku pracy uregulowanej w przepisie art. 41 k.p. ustawodawca wprowadził limity czasowe również w wypadku fragmentarycznego środka ochrony zatrudnienia z powołania ustanowionego w przepisie art. $72 \S 1$ zd. 1. k.p. W konsekwencji w sytuacji, w której usprawiedliwiona nieobecność trwa dłużej niż okres przewidziany w art. 53 §1-2 k.p., organ, który pracownika powołał, może rozwiązać stosunek pracy bez wypowiedzenia (por. art. $72 \S 1$ zd. 2 k.p.).

W zakresie normy prawnej wynikającej z tej regulacji możliwe jest wystąpienie dwóch sytuacji. Pierwsza $\mathrm{z}$ nich miałaby miejsce $\mathrm{w}$ przypadku podejmowania decyzji zmierzającej do pozbawienia powołanego pracownika stanowiska w czasie przekraczającej już limity wynikające z przepisów art. 53 k.p. jego usprawiedliwionej nieobecności w pracy. Na mocy aktu odwołania wydanego przez organ, który pracownika powołał, doszłoby do jednoczesnego ustania więzi publicznoprawnej i pracowniczej.

Ze względu na zagwarantowaną przez ustawodawcę możliwość odwołania pracownika w każdym czasie, również podczas trwającej już jego nieobecności w pracy, może dojść do wystąpienia drugiej z możliwych sytuacji. Ponieważ mechanizm ochronny przewidziany przez regulację art. $72 \S 1$ zd. 1 k.p. działa tylko dopóty, dopóki usprawiedliwiona nieobecność zatrudnionego nie przekroczy ustalonych limitów czasowych, stosunek pracy pracownika odwołanego ze skutkiem równoznacznym z wypowiedzeniem może po ich upływie zostać rozwiązany bez wypowiedzenia ${ }^{21}$. Wymaga to jednak dokonania odrębnej czynności prawnej, a więc złożenia oświadczenia woli o rozwiązaniu umowy o pracę bez wypowiedzenia przy zachowaniu rygorów przewidzianych w przepisach o rozwiązywaniu umów o pracę $\mathrm{w}$ trybie niezwłocznym z wyjątkiem norm dotyczących trybu postępowania przy rozwiązywaniu umów o pracę 22 . Upływ wskazanych w przepisie art. 53 k.p. okresów w analizowanej sytuacji nie powoduje konieczności ponownego odwoływania ze stanowiska pracownika wcześniej odwołanego. Ustawodawca uprawnienie do natychmiastowego zerwania więzi pracowniczej przyznaje organowi, który uprzednio odwołał pracownika ze skutkiem równoznacznym z wypowiedzeniem. Zgodnie z przepisem art. $70 \S 1^{2}$ k.p. przepisy Kodeksu pracy stosuje się do odwołania, jeżeli unormowania szczególne nie stanowią inaczej. Ze względu na „oderwanie” czynności skutkującej niezwłocznym ustaniem więzi pracowniczej od aktu odwołania ze stanowiska, w niektórych przypadkach pierwotna kompetencja organu (często kolegialnego) do powołania i odwołania ze stanowiska nie obejmuje swoim zakresem dodatkowej, odrębnej czynności skutkującej niezwłocznym ustaniem zatrudnienia. Uprawnienie do jej dokonania, na mocy upoważnienia zawartego w ustawach, przy-

${ }^{21}$ Nie dotyczy to sytuacji, gdy pracownik po zakończeniu spowodowanej chorobą nieobecności w pracy nie podejmuje zatrudnienia, gdyż nie ma takiego obowiązku; zob. wyrok SN z dnia 15 października 1999 roku, sygn. I PKN 245/99, OSNP 2001, nr 5, poz. 144.

22 Por. W. Sanetra, [w:] J. Iwulski, W. Sanetra, Kodeks pracy. Komentarz, Warszawa 2011, s. 557-558; zob. też uchwała SN z dnia 27 sierpnia 1985 roku, sygn. III PZP 30/85, LEX nr 12905. 
sługuje zaś podmiotowi, który w imieniu pracodawcy podejmuje czynności wobec pracowników ${ }^{23}$. Długotrwała usprawiedliwiona nieobecność pracownika stanowi bowiem nową przyczynę umożliwiającą złożenie odrębnego od odwołania ze stanowiska (dokonywanego już po nim) oświadczenia woli w przedmiocie rozwiązania stosunku pracy na mocy art. $53 \S 1$ lub 2 k.p. ${ }^{24}$

Należy podkreślić, że natychmiastowe rozwiązanie stosunku pracy z powołania z powodu wystąpienia okoliczności określonych w przepisie art. 53 k.p. nie ma obligatoryjnego charakteru. Decyzja w tym zakresie pozostawiona została uprawnionemu do dokonania tej czynności podmiotowi. Jeżeli takie oświadczenie nie zostanie złożone, stosunek pracy będzie trwał aż do upływu okresu wypowiedzenia, który w takim wypadku rozpocznie swój bieg dopiero po powrocie pracownika do pracy ${ }^{25}$. Jednocześnie jednak pracownik odwołany ze stanowiska ze skutkami wypowiedzenia umowy o pracę jest obowiązany powiadomić pracodawcę o ustaniu przyczyny usprawiedliwiającej nieobecność w pracy, w szczególności spowodowaną niezdolnością do pracy wskutek długotrwałej choroby ${ }^{26}$. Niepowiadomienie pracodawcy o odzyskaniu zdolności do pracy przez pracownika odwołanego ze stanowiska powoduje, że pracodawca może rozwiązać stosunek pracy bez wypowiedzenia z powodu nieobecności trwającej dłużej niż okresy ochronne ${ }^{27}$.

\subsection{ODWOŁANIE PRACOWNICY W CIĄŻY I PRACOWNIKA W WIEKU PRZEDEMERYTALNYM}

W odniesieniu do tych kategorii pracowników ustawodawca posłużył się odmienną konstrukcją ochrony szczególnej stosunku pracy z powołania. Z unormowania przyjętego w przepisie art. $72 \S 2 \mathrm{k}$.p. wynika obowiązek organu odwołującego zapewnienia tym pracownikom innej pracy, odpowiedniej ze względu na ich kwalifikacje zawodowe, a także gwarancja, że przez czas równy okresowi wypowiedzenia otrzymywać będą wynagrodzenie w wysokości przysługującej przed odwołaniem. W tym wypadku regulacje ochronne mają zatem charakter mocniejszy w porównaniu do pierwszej z analizowanych grup, jako że umożliwiają pracownikowi pozostanie w stosunku pracy. Dalsze zatrudnienie kontynuowane

23 W niektórych przypadkach taki podmiot posiada również kompetencję do zarówno powołania, jak i odwołania pracownika — na przykład wójt (burmistrz, prezydent miasta) w odniesieniu do swoich zastępców.

24 Zob. wyrok SN z dnia 14 kwietnia 2010 roku, sygn. III PK 63/09, LEX nr 602056 $\mathrm{w}$ odniesieniu do rozwiązania bez wypowiedzenia przez burmistrza stosunku pracy z sekretarzem (skarbnikiem) gminy odwołanym ze stanowiska ze skutkiem równoznacznym z wypowiedzeniem przez radę gminy; zob. też wyrok SN z dnia 30 maja 2001 roku, sygn. I PKN 421/00, OSNP 2003, nr 7, poz. 171.

25 Por. W. Sanetra, op. cit., s. 558.

26 Tak: A.M. Świątkowski, Kodeks pracy. Komentarz, Warszawa 2016, s. 455.

27 Zob. wyrok SN z dnia 11 lutego 2005 roku, sygn. I PK 168/04, OSP 2006, nr 1, poz. 8 z glosą Z. Niedbały. 
jest $\mathrm{u}$ dotychczasowego pracodawcy, choć na innym stanowisku. Do rozwiązania stosunku pracy dojdzie jedynie w przypadku, gdy szczególnie chroniony pracownik nie wyrazi zgody na podjęcie innej pracy. Stosunek pracy ulega w takiej sytuacji rozwiązaniu z upływem czasu równego okresowi wypowiedzenia, którego bieg rozpoczyna się od dnia zaproponowania na piśmie innej pracy.

W odróżnieniu od unormowań ochronnych dotyczących umów o pracę uregulowanych w przepisach art. 177 k.p. analizowana regulacja w sposób wyraźny obejmuje zakresem podmiotowym wyłącznie kobiety w ciąży. Nie dotyczy zatem pracowników korzystających z uprawnień związanych z rodzicielstwem przysługujących pracownikom po urodzeniu dziecka. W nauce prawa pracy dominuje bowiem stanowisko, zgodnie z którym urlopy: macierzyński, rodzicielski, ojcowski i wychowawczy stanowią okresy usprawiedliwionej nieobecności w pracy, a korzystającemu z nich pracownikowi przysługuje ochrona gwarantowana przez przepis art. $72 \S 1$ zd. 1 k.p. Na organie odwołującym nie spoczywa więc w tym wypadku obowiązek zapewnienia pracownikowi innej pracy; dopiero ukończenie korzystania ze wskazanych uprawnień rozpoczyna bieg przysługującego pracownikowi okresu wypowiedzenia ${ }^{28}$. Przepis art. $72 \S 2$ k.p., wyraźnie odwołujący się do okresu ciąży, nie może być bowiem interpretowany rozszerzająco. Na drugim biegunie znajduje się zapatrywanie, zgodnie z którym nieodniesienie się przez ustawodawcę $\mathrm{w}$ analizowanej regulacji do urlopu macierzyńskiego powoduje, że wynikające $\mathrm{z}$ przepisu art. 177 k.p. zasady ochrony kobiet w tym czasie nie ulegają zmianie. Oznacza to, że jeśli podmiot zatrudniający nie zdecyduje o odwołaniu kobiety w okresie ciąży, to nie będzie mógł już tego zrobić w okresie korzystania przez nią z urlopu macierzyńskiego ${ }^{29}$. Przepisy art. 72 k.p. stosowane w związku z art. 69 k.p. wprowadzają regulację szczególną wobec unormowania dotyczącego umowy o pracę na czas nieokreślony, a regulacja wyjątkowa nie może być interpretowana w sposób rozszerzający. Za przyjęciem tego stanowiska mają przemawiać również argumenty wynikające z wykładni systemowej, w której świetle wątpliwe wydaje się uznanie, że usprawiedliwiona nieobecność w pracy z powodu urlopu macierzyńskiego może być traktowana jako taka nieobecność na gruncie art. 41 k.p. ${ }^{30}$ Choć w sposób wyraźny odniesiono się tu jedynie do urlopu macierzyńskiego, zapatrywanie to należałoby odnieść także do urlopu rodzicielskiego i ojcowskiego. Biorąc pod uwagę treść przepisu art. 177 § 1 k.p., nie ma bowiem podstaw do różnicowania sytuacji pracowników korzystających również z tych uprawnien $^{31}$. Zapatrywanie to, choć niewątpliwie korzystne dla pracowników po-

28 Zob. przyp. 16-17.

29 Tak: M. Włodarczyk, [w:] System prawa pracy, t. 4. Indywidualne prawo pracy. Pozaumowne stosunki pracy, red. K.W. Baran, Warszawa 2017, s. 165.

30 Ibidem, s. 165-166.

31 Akceptacja argumentów wynikających z reguł wykładni systemowej powinna prowadzić do rozważenia utrzymania na tym sam poziomie co określona w przepisach art. 186 [8] k.p. ochrony szczególnej zatrudnienia pracownika powołanego podczas korzystania z urlopu wychowawczego. 
wołanych korzystających z tego rodzaju przerw w wykonywaniu pracy, należy ocenić jako zbyt daleko idące. Podkreślenia wymaga to, że regulacji ochronnych zawartych zarówno w Kodeksie pracy, jak i w przepisach pozakodeksowych ${ }^{32}$ nie można rozciągać na element publicznoprawny złożonego stosunku zatrudnienia, w jakim pozostaje powołany pracownik. Gwarancje ochrony prawnej nie obejmują nieusuwalności ze stanowiska lub pozbawienia określonej funkcji. Dotyczą one, choć w różnym zakresie, jedynie sfery pracowniczej ${ }^{33}$. W konsekwencji oznacza to, że uprawniony organ może odwołać pracownika również w czasie trwania urlopu macierzyńskiego czy rodzicielskiego. W tych jednak okresach nie dojdzie natomiast do finalnego skutku odwołania w postaci całkowitego zerwania więzi łączącej pracownika z pracodawcą, który musiałby nastąpić dopiero po ich upływie. Korzystniejsze dla pracownika byłoby zatem przyjęcie pierwszego z przedstawionych zapatrywań i uznanie, że wskazane urlopy stanowią okresy usprawiedliwionej nieobecności w pracy, po której upływie dopiero rozpoczyna się okres przysługującego pracownikowi okresu wypowiedzenia.

Konstrukcja ochronna stosunku pracy z powołania obejmująca kobiety w ciąży zgodnie z regulacją art. $72 \S 3$ k.p. znajdzie zastosowanie także w odniesieniu do pracowników, którym brakuje nie więcej niż 2 lata do nabycia prawa do emerytury z Funduszu Ubezpieczeń Społecznych. Oceniając wskazaną regulację, w nauce prawa pracy zwrócono uwagę na jej niespójności w relacji z przepisem art. 39 k.p. wprowadzającym czteroletni okres ochrony przed wypowiedzeniem. Krótszy, dwuletni, okres ochronny może stanowić wynik niestaranności ustawodawcy, który przy okazji ostatniej zmiany art. 39 k.p. ${ }^{34}$ nie zmienił treści art. $72 \S 3$ k.p., lub wynikać z mniejszej stabilizacji zatrudnienia pracowników powołanych ${ }^{35}$. Istotniejszy jest jednak fakt, że regulacja ochronna dotycząca pracowników powołanych odnosi się do lat brakujących do nabycia emerytury z Funduszu Ubezpieczeń Społecznych, co mogłoby sugerować, że w odniesieniu do pracowników zatrudnionych na podstawie powołania chodzi o wszystkie przypadki nabycia prawa do świadczenia emerytalnego, w tym prawa do wcześniejszej emerytury. Przeciwko takiej interpretacji zdecydowanie wypowiadają się przedstawiciele doktryny oraz judykatura ${ }^{36}$.

Jak już wspomniano, w razie odwołania ze stanowiska pracowników objętych ochroną szczególną wynikającą z przepisu art. 72 § 2-3 k.p. na organie odwołującym spoczywa obowiązek zapewnienia tej kategorii zatrudnionym innej pracy,

32 Zob. m.in. art. 32 ustawy z dnia 23 maja 1991 roku o związkach zawodowych (tekst jedn. Dz.U. z 2019 r. poz. 263 z późn. zm.) czy też art. 25 § 2 ustawy z dnia 8 marca 1990 roku o samorządzie gminnym (tekst jedn. Dz.U. z 2019 r. poz. 506).

33 Zob. m.in. uchwała SN z dnia 14 lipca 1992 roku, sygn. I PZP 42/92, LEX nr 14959.

34 Zmiana dokonana została ustawą z dnia 30 kwietnia 2004 roku o świadczeniach przedemerytalnych (Dz.U. z 2004 r. Nr 120, poz. 1252).

35 Tak: T. Wrocławska, Kodeksowa szczególna ochrona trwałości stosunku pracy pracowników w wieku przedemerytalnym, [w:] 40 lat kodeksu pracy, red. Z. Góral, M. Mielczarek, Warszawa 2015, LEX.

36 Ibidem; zob. też powoływana tam literatura i orzecznictwo. 
odpowiedniej ze względu na ich kwalifikacje zawodowe. Przyjmuje się, że propozycja podjęcia innej pracy ma charakter oferty zawarcia nowego stosunku pracy, do której z mocy art. 300 k.p. stosuje się art. 66 § 2 k.c. ${ }^{37}$

Przez propozycję pracy „odpowiedniej” w rozumieniu przytoczonych unormowań należy rozumieć taką, w której kwalifikacje zawodowe pracownika zostaną należycie wykorzystane; propozycja powinna więc uwzględniać nie tylko profil wykształcenia pracownika, lecz także jego doświadczenie zawodowe, dodatkowo nabytą wiedzę specjalistyczną, również z dziedzin pokrewnych do posiadanego wykształcenia ${ }^{38}$. Uzależnienie powierzenia innej pracy od tego, by odpowiadała ona kwalifikacjom pracownika, nie oznacza, że może to być praca wyraźnie odbiegająca charakterem od pracy dotychczas wykonywanej, nawet jeśli pracownik ma do jej wykonywania wystarczające kwalifikacje ${ }^{39}$. Zaproponowanie stanowiska znajdującego się w hierarchii zaszeregowania kilka kategorii niżej niż dotychczas zajmowane może zostać uznane za naruszenie jego godności, a więc niezgodne z zasadami współżycia społecznego, w szczególności jeżeli nosiło znamiona intencjonalnego, świadomego i natężonego złą wolą działania zmierzającego do jego poniżenia i zdyskredytowania. Tego rodzaju propozycje oceniane są w orzecznictwie jako wysoce niestosowne (niewłaściwe) i zmierzające do obejścia prawa ${ }^{40}$.

Proponowane stanowisko musi istnieć — tylko wtedy możliwe jest określenie przypisanego do niego zakresu obowiązków. Nie oznacza to jednak obowiązku jego wcześniejszego funkcjonowania w strukturze właściwego podmiotu. Jeżeli organem odwołującym jest organ pracodawcy, u którego osoba odwołana jest zatrudniona, propozycja innej pracy jest ofertą nawiązania nowego stosunku pracy na innym stanowisku u tego samego pracodawcy. Natomiast organ odwołujący niebędący organem pracodawcy nie może złożyć skutecznej oferty zatrudnienia kobiety ciężarnej czy pracownika w wieku przedemerytalnym u tego pracodawcy. Propozycje zewnętrznego organu złożone wobec odwołanego pracownika nie są bowiem wiążące dla samego pracodawcy. Nawiązanie stosunku pracy zawsze wymaga zgodnego oświadczenia woli stron. Zapewnienie innej pracy w tym wypadku może polegać jedynie na złożeniu osobie odwołanej oferty zatrudnienia na stanowisku, którym organ odwołujący dysponuje ${ }^{41}$. Organ dokonujący odwołania pracownika ze stanowiska niebędący organem wewnętrznym pracodawcy

37 Tak m.in.: SN w uzasadnieniu wyroku z dnia 18 maja 2010 roku, sygn. I PK 15/10, OSNP 2011, nr 21-22, poz. 272.

38 Szerzej na ten temat zob. K. Jaśkowski, Rozwiąanie stosunku pracy pracownika zatrudnionego na podstawie powolania, „Państwo i Prawo” 1976, nr 1, s. 175; zob. też wyrok SN z dnia 24 września 2004 roku, sygn. II PK 28/04, LEX nr 122862.

39 Por. wyrok SN z dnia 21 lutego 2008 roku, sygn. II PK 171/07, LEX nr 492989.

40 Por. wyrok SN z dnia 21 lutego 2008 roku; wyrok SN z dnia 24 września 2004 roku, sygn. II PK 28/04, LEX nr 122862.

41 Tak: Ł. Pisarczyk, T. Zieliński, [w:] Kodeks pracy. Komentarz, red. L. Florek, Warszawa 2017, s. 472; por. K. Jaśkowski, Rozwiązanie stosunku pracy..., s. 175; oraz P. Kłosiewicz, Stosunek pracy z powołania, „Studia i Materiały IPSS” 7, Warszawa 1974. 
powinien zatem złożyć odwoływanemu pracownikowi propozycję innej pracy w uzgodnieniu z dotychczasowym pracodawcą. Pracownik otrzymując propozycję zatrudnienia na nowych warunkach, musi mieć możliwość ich oceny pod kątem wymagań stawianych przez art. $72 \S 2$ k.p. Oferta powinna być więc konkretna i zrozumiała dla adresata, tak aby zdawał sobie sprawę z jej znaczenia i mógł prawidłowo na nią odpowiedziećt2

Propozycja powinna być przedstawiona w formie pisemnej, w czasie dogodnym dla organu odwołującego. Nie musi być zatem złożona równocześnie z odwołaniem ze stanowiska. Niezłożenie oferty przez organ odwołujący powoduje jednak stan, w którym dotychczasowy stosunek pracy pracownika odwołanego trwa, mimo iż wskutek odwołania nie sprawuje już danej funkcji (nie piastuje stanowiska).

W nauce prawa pracy reprezentowane są dwa stanowiska odnoszące się do okresu, przez który trwa obowiązek wypłaty wynagrodzenia pracownikowi, któremu nie złożono oferty nowego zatrudnienia. Zgodnie z pierwszym z nich obowiązek wypłaty dotychczasowego wynagrodzenia aktualizuje się w dniu odwołania pracownika i trwa przez czas równy okresowi wypowiedzenia, mimo iż - z powodu niezłożenia oferty zatrudnienia na nowych warunkach - samo wypowiedzenie nie rozpoczyna biegu ${ }^{43}$. Po upływie tego okresu, mimo że stosunek pracy trwa, pracodawca, który nie przedstawił oferty zatrudnienia na nowych warunkach, nie ma obowiązku wypłacania wynagrodzenia odwołanym pracownikom objętym ochroną przewidzianą w art. $72 \S 2$ k.p. Takim pracownikom przysługuje za to roszczenie o odszkodowanie na podstawie art. 471 ustawy z dnia 23 kwietnia 1964 roku - Kodeks cywilny ${ }^{44}$ w zw. z art. 300 k.p. ${ }^{45}$

Na przeciwnym biegunie znajduje się stanowisko negujące tak zwane sztuczne rozgraniczenie okresu nazwanego w przepisie art. $72 \S 2$ k.p „okresem równym okresowi wypowiedzenia" na dwa — o różnym okresie początkowym — moment odwołania i złożenia oferty pracy. Rozdzielenie to powoduje, że skutki upływu zwłaszcza pierwszego $\mathrm{z}$ nich jawią się jako nieunormowane w przepisach prawa pracy, „wymuszając” stosowanie Kodeksu cywilnego ${ }^{46}$. Tymczasem przyjęcie, że w obu zdaniach wskazanej regulacji ma chodzić o ten sam okres, biegnący od momentu złożenia oferty nowej pracy, usuwa te problemy. W konsekwencji zarówno przed złożeniem oferty, jak i w okresie równym okresowi wypowiedzenia odwołanemu przysługuje „dotychczasowe wynagrodzenie”, w przypadku braku oferty „dotychczasowy” stosunek pracy trwa nadal (bez obowiązku świadczenia pracy) z dotychczasowym wynagrodzeniem (gotowość świadczenia pracy), w wypadku zaś przyjęcia zaproponowanych warunków po upływie okresu równego okresowi

\footnotetext{
42 Zob. wyrok SN z dnia 18 maja 2010 roku.

43 Tak: A.M. Świątkowski, op. cit., s. 456-457.

44 Tekst jedn. Dz.U. z 2018 r. poz. 1025 z późn. zm.

45 A.M. Świątkowski, op. cit., s. 457.

46 Tak: B.M. Ćwiertniak, op. cit., s. 557-558.
} 
wypowiedzenia trwa stosunek pracy na nowych warunkach (w tym płacowych) ${ }^{47}$. Pracownicy objęci ochroną szczególną będą mogli zasadnie domagać się wypłaty wynagrodzenia do końca okresu ochronnego ${ }^{48}$. Słusznie zatem stwierdzono, że to w interesie pracodawcy jest możliwe szybkie złożenie oferty „innej pracy”, uruchamiającej bieg okresu równego okresowi wypowiedzenia, o ile nie nastąpiło ono w dacie odwołania ze stanowiska ${ }^{49}$. Dodatkowo należy podkreślić, że realizacja w pełnym zakresie ochronnego celu analizowanej instytucji będzie możliwa pod warunkiem przyjęcia, że okres wypowiedzenia, po którego upływie dochodzi do rozwiązania stosunku pracy, nie rozpocznie biegu nie tylko przypadku niezłożenia oferty ze strony zobowiązanego do jej złożenia podmiotu, lecz także w przypadku zaproponowania pracy „nieodpowiedniej”"50.

W odróżnieniu od mechanizmu prawnego wynikającego z przepisu art. $72 \S 1$ k.p. prowadzącego jedynie do przedłużenia trwania dotychczasowego stosunku pracy odwołanego pracownika zatrudnionego na podstawie powołania (zwykle przy tym przy braku obowiązku świadczenia pracy) w razie przyjęcia oferty pracy przez pracownicę w ciąży lub pracownika w wieku przedemerytalnym następuje kontynuacja zatrudnienia, co do zasady u dotychczasowego pracodawcy, choć na innym stanowisku pracy i na nowej podstawie prawnej — umowie o pracę ${ }^{51}$. Najbardziej adekwatne w tym wypadku wydaje się przyjęcie, że źródło stosunku pracy będzie w tym przypadku stanowić umowa na czas nieokreślony. Zatrudnienie terminowe (w szczególności bardzo krótkie) nie realizowałoby bowiem ochronnego celu analizowanej instytucji.

\section{THE SPECIAL PROTECTION OF EMPLOYMENT RELATIONSHIP ON THE BASIS OF APPOINTMENT RESULTING FROM THE LABOUR CODE}

\section{Summary}

The subject matter of this study is an analysis of the legal mechanisms resulting from the provisions of the Labour Code which concern the special protection of an employment relationship which is based on appointment, regarding both their subjective scope as well as the terms of the correctness of their applications by the appellant (the employer). Among the ways of establishing an employment relationship, appointment stands out by providing the smallest degree of stabilization, not only because of the scope of the claims that recalled employees are entitled to and the lack of the possibility of applying the usual modes of conduct for the termination of an employment contract, but also because of the nature of the special protection, which allows for the appointed employee to be recalled and poorly protects against the termination of the employment relationship. Measures for the protection of

\footnotetext{
47 Ibidem.

48 K. Jaśkowski, Rozwiąanie stosunku pracy..., s. 176.

49 Tak B.M. Ćwiertniak, op. cit., s. 558.

50 Por. K. Jaśkowski, [w:] K. Jaśkowski, E. Maniewska, op. cit., s. 341.

51 Tak m.in.: SN w wyroku z dnia 18 maja 2010 roku.
} 
an employment relationship on the basis of appointment, resulting from the provisions of the Labour Code, have a limited subjective range. The legislature has also resigned from an absolute ban on the termination of an employment relationship and allows only the extension of the duration of the existing relationship or the continuation of an employment with the previous employer, but on a different legal basis.

Keywords: appointment, pregnancy, protection before reaching retirement age, special protection

\section{BIBLIOGRAFIA}

Czechowski M., Status prawny szefa stużby specjalnej oraz komendanta, szefa i dyrektora generalnego stużby umundurowanej, [w:] Księga pamiątkowa w piata rocznice śmierci profesora Andrzeja Kijowskiego, red. Z. Niedbała, Warszawa 2010.

Ćwiertniak B.M., [w:] Kodeks pracy. Komentarz, red. K.W. Baran, Warszawa 2014.

Dubowik A., Powołanie jako podstawa nawiąania stosunku pracy a reforma prawa pracy, „Praca i Zabezpieczenie Społeczne" 2004, nr 6.

Giedrewicz-Niewińska A., [w:] Kodeks pracy. Komentarz, red. K. Walczak, wyd. 27, Legalis 2018. Góral Z., Prawo pracy w samorzadzie terytorialnym, Warszawa 1999.

Jaśkowski K., [w:] K. Jaśkowski, E. Maniewska, Kodeks pracy. Komentarz, red. K. Jaśkowski, t. 1, Warszawa 2014.

Jaśkowski K., Rozwiąanie stosunku pracy pracownika zatrudnionego na podstawie powotania, „Państwo i Prawo” 1976, nr 1.

Kłosiewicz P., Stosunek pracy z powołania, „Studia i Materiały IPSS” 7, Warszawa 1974.

Korus. P., [w:] Kodeks pracy. Komentarz, red. A. Sobczyk, Warszawa 2015.

Kuczyński T., [w:] H. Szurgacz, Z. Kubot, T. Kuczyński, A. Tomanek, Prawo pracy. Zarys wykładu, wyd. 4, Warszawa 2016.

Liszcz T., Pozaumowne stosunki pracy, [w:] Prawo pracy RP w obliczu przemian, red. M. Matey-Tyrowicz, T. Zieliński, Warszawa 2006.

Romer M.T., Kodeks pracy. Komentarz, Warszawa 2012.

Sanetra W., [w:] J. Iwulski, W. Sanetra, Kodeks pracy. Komentarz, Warszawa 2011.

Skoczyński J., [w:] Kodeks pracy. Komentarz, red. Z. Salwa, Warszawa 1999.

Stelina J., [w:] Kodeks pracy z komentarzem, red. U. Jackowiak, Gdynia 2004.

Szewczyk H., Stabilizacja zatrudnienia pracowników samorzadowych petniacych funkcję z wyboru oraz powołania, [w:] Z problematyki prawa pracy i polityki socjalnej, t. 12, red. A. Nowak, Katowice 1997.

Świątkowski A.M., Kodeks pracy. Komentarz, Warszawa 2016.

Włodarczyk M., [w:] System prawa pracy, t. 4. Indywidualne prawo pracy. Pozaumowne stosunki pracy, red. K.W. Baran, Warszawa 2017.

Wratny J., Kodeks pracy. Komentarz, Legalis 2016.

Wrocławska T., Kodeksowa szczególna ochrona trwałości stosunku pracy pracowników w wieku przedemerytalnym, [w:] 40 lat kodeksu pracy, red. Z. Góral, M. Mielczarek, Warszawa 2015. 